SUPPORTING INFORMATION

\title{
Sustainable Chemistry: Solubilization of phosphorus from insoluble phosphate material hydroxyapatite with ozonized biochar
}

\author{
Oumar Sacko ${ }^{1}$, Rachel Whiteman ${ }^{1}$, Gyanendra Kharel ${ }^{1}$, Sandeep Kumar ${ }^{2}$ and James W. Lee ${ }^{1 *}$ \\ ${ }^{1}$ Department of Chemistry and Biochemistry, Old Dominion University, 110 Alfriend Chemistry \\ Building, Norfolk, VA 23529 USA \\ ${ }^{2}$ Department of Civil and Environmental Engineering, Old Dominion University, 137C Kaufman \\ Hall, Norfolk, VA 23529
}

*Corresponding Author Email: jwlee@odu.edu

Additional experimental data: 11 Figures and 7 Tables on the following pages S1-S19.

\section{List of Figures and Tables}

The Figures and Tables report additional experimental data from the hydroxyapatite solubilization assay. Briefly, Figures S1-S11 below present the data on the $\mathrm{pH}$, the amount of calcium and phosphorus measured during the hydroxyapatite assay, and the calcium removal assay. Table S1 below lists the properties of biochars used in the experiment. Table S2 presents the experimental set up for the hydroxyapatite assay. Tables S3-S6 present the detailed numerical data of the $\mathrm{pH}$, calcium concentration and phosphate concentration measured in the hydroxyapatite assay experiments. Table S7 presents the numerical data of the calcium removal assay.

Key words: Phosphorus sustainability, ozonized biochar, phosphorus solubilization, unlocking phosphorus from insoluble phosphate, hydroxyapatite 
Table S1: Cation Exchange Capacity and $\mathrm{pH}$ of the biochars and their respective filtrate. The CEC was measured for all types of biochar and the recorded values are the averages for the 6 replicates done for each biochar type $\pm \mathrm{SD}(\mathrm{n}=6)$. The wet-ozonized biochar had the highest CEC $(14.4 \pm 1.5 \mathrm{cmol} / \mathrm{kg})$. The $\mathrm{pH}$ was measured in duplicate for all types of biochar $\pm \mathrm{SD}(\mathrm{n}=2)$. The $\mathrm{pH}$ results revealed that the wet-ozonized biochar was the most acidic $(3.60 \pm 0.01)$. The $\mathrm{pH}$ of the biochar filtrates was also measured in duplicate \pm $\mathrm{SD}(\mathrm{n}=2)$.

\begin{tabular}{|c|c|c|c|}
\hline & $\begin{array}{c}\text { Non-ozone } \\
\text { treated biochar }\end{array}$ & $\begin{array}{c}\text { Wet-ozone treated } \\
\text { biochar }\end{array}$ & $\begin{array}{c}\text { Dry-ozone treated } \\
\text { biochar }\end{array}$ \\
\hline $\begin{array}{c}\text { Cation Exchange } \\
\text { Capacity }(\mathrm{cmol} / \mathrm{kg})\end{array}$ & $10.4( \pm 1.2)$ & $14.4( \pm 1.5)$ & $13.2( \pm 0.9)$ \\
\hline $\mathrm{pH}$ of the biochar & $5.64( \pm 0.02)$ & $3.60( \pm 0.01)$ & $3.96( \pm 0.01)$ \\
\hline $\begin{array}{c}\mathrm{pH} \text { of the filtrate } \\
\text { from the biochar }\end{array}$ & $6.49( \pm 0.05)$ & $2.53( \pm 0.01)$ & $3.00( \pm 0.04)$ \\
\hline
\end{tabular}

Table S2: Experimental set-up of the Hydroxyapatite Assay. For the collection of the filtrate of the nonozonized and dry-ozonized biochar, the first wash which used $35 \mathrm{~mL}$ of water was collected by filtration. For the wet-ozone treatment, the $35 \mathrm{~mL}$ of water that was used during the ozonization was also collected by filtration. The samples that used the biochar filtrate were done using the $35 \mathrm{~mL}$ filtration wash. Upon collection of those filtrate, the biochar was further washed with $300 \mathrm{~mL}$ of water for every $1.5 \mathrm{~g}$ of biochar to remove other unbound particles and ashes. The samples that used biochar for the incubation were done with that cleaned and washed biochar to ensure that the effect of solubilization of hydroxyapatite is majorly due to the biochar and its surface functional groups. Each sample was prepared in triplicate $(n=3)$.

\begin{tabular}{|c|c|c|c|c|}
\hline & Blank & Non-ozonized & Wet-ozonized & Dry-ozonized \\
\hline $\begin{array}{c}\text { Water } \\
+\end{array}$ & & & & \\
Biochar & $12 \mathrm{~mL}$ milli-Q & $\begin{array}{c}12 \mathrm{~mL} \text { milli-Q } \\
+0.5 \mathrm{~g} \text { biochar }\end{array}$ & $\begin{array}{c}12 \mathrm{~mL} \text { milli-Q } \\
+0.5 \mathrm{~g} \text { biochar }\end{array}$ & $\begin{array}{c}12 \mathrm{~mL} \text { milli-Q } \\
+0.5 \mathrm{~g} \text { biochar }\end{array}$ \\
\hline $\begin{array}{c}\text { Water } \\
+\end{array}$ & & & & \\
$\begin{array}{c}\text { Hydroxyapatite (HA) } \\
+\end{array}$ & $12 \mathrm{~mL}$ milli-Q \\
$+0.25 \mathrm{~g}$ of HA & $\begin{array}{c}12 \mathrm{~mL} \text { milli-Q } \\
+0.25 \mathrm{~g} \mathrm{HA} \\
+0.5 \mathrm{~g} \text { biochar }\end{array}$ & $\begin{array}{c}12 \mathrm{~mL} \text { milli-Q } \\
+0.25 \mathrm{~g} \mathrm{HA} \\
+0.5 \mathrm{~g} \text { biochar }\end{array}$ & $\begin{array}{c}12 \mathrm{~mL} \text { milli-Q } \\
+0.25 \mathrm{~g} \mathrm{HA} \\
+0.5 \mathrm{~g} \text { biochar }\end{array}$ \\
\hline
\end{tabular}




\begin{tabular}{|c|c|c|c|c|}
\hline Biochar filtrate & $\mathrm{N} / \mathrm{A}$ & $\begin{array}{c}12 \text { mL non- } \\
\text { ozonized } \\
\text { biochar filtrate }\end{array}$ & $\begin{array}{c}12 \mathrm{~mL} \text { wet- } \\
\text { ozonized } \\
\text { biochar filtrate }\end{array}$ & $\begin{array}{c}12 \mathrm{~mL} \text { dry- } \\
\text { ozonized } \\
\text { biochar filtrate }\end{array}$ \\
\hline $\begin{array}{c}\text { Biochar filtrate } \\
+ \\
\text { Hydroxyapatite (HA) }\end{array}$ & $\mathrm{N} / \mathrm{A}$ & $\begin{array}{l}12 \mathrm{~mL} \text { non- } \\
\text { ozonized } \\
\text { biochar filtrate } \\
+0.25 \mathrm{~g} \mathrm{HA}\end{array}$ & $\begin{array}{l}12 \mathrm{~mL} \text { wet- } \\
\text { ozonized } \\
\text { biochar filtrate } \\
+0.25 \mathrm{~g} \mathrm{HA}\end{array}$ & $\begin{array}{l}12 \mathrm{~mL} \text { dry- } \\
\text { ozonized } \\
\text { biochar filtrate } \\
+0.25 \mathrm{~g} \mathrm{HA}\end{array}$ \\
\hline $\begin{array}{c}\text { Biochar filtrate } \\
+ \\
\text { Hydroxyapatite (HA) } \\
+ \\
\text { Biochar } \\
\end{array}$ & $\mathrm{N} / \mathrm{A}$ & $\begin{array}{l}12 \text { mL non- } \\
\text { ozonized } \\
\text { biochar filtrate } \\
+0.25 \mathrm{~g} \mathrm{HA} \\
+0.5 \mathrm{~g} \text { biochar } \\
\end{array}$ & $\begin{array}{l}12 \mathrm{~mL} \text { wet- } \\
\text { ozonized } \\
\text { biochar filtrate } \\
+0.25 \mathrm{~g} \mathrm{HA} \\
+0.5 \mathrm{~g} \text { biochar } \\
\end{array}$ & $\begin{array}{l}12 \mathrm{~mL} \text { dry- } \\
\text { ozonized } \\
\text { biochar filtrate } \\
+0.25 \mathrm{~g} \mathrm{HA} \\
+0.5 \mathrm{~g} \text { biochar } \\
\end{array}$ \\
\hline
\end{tabular}

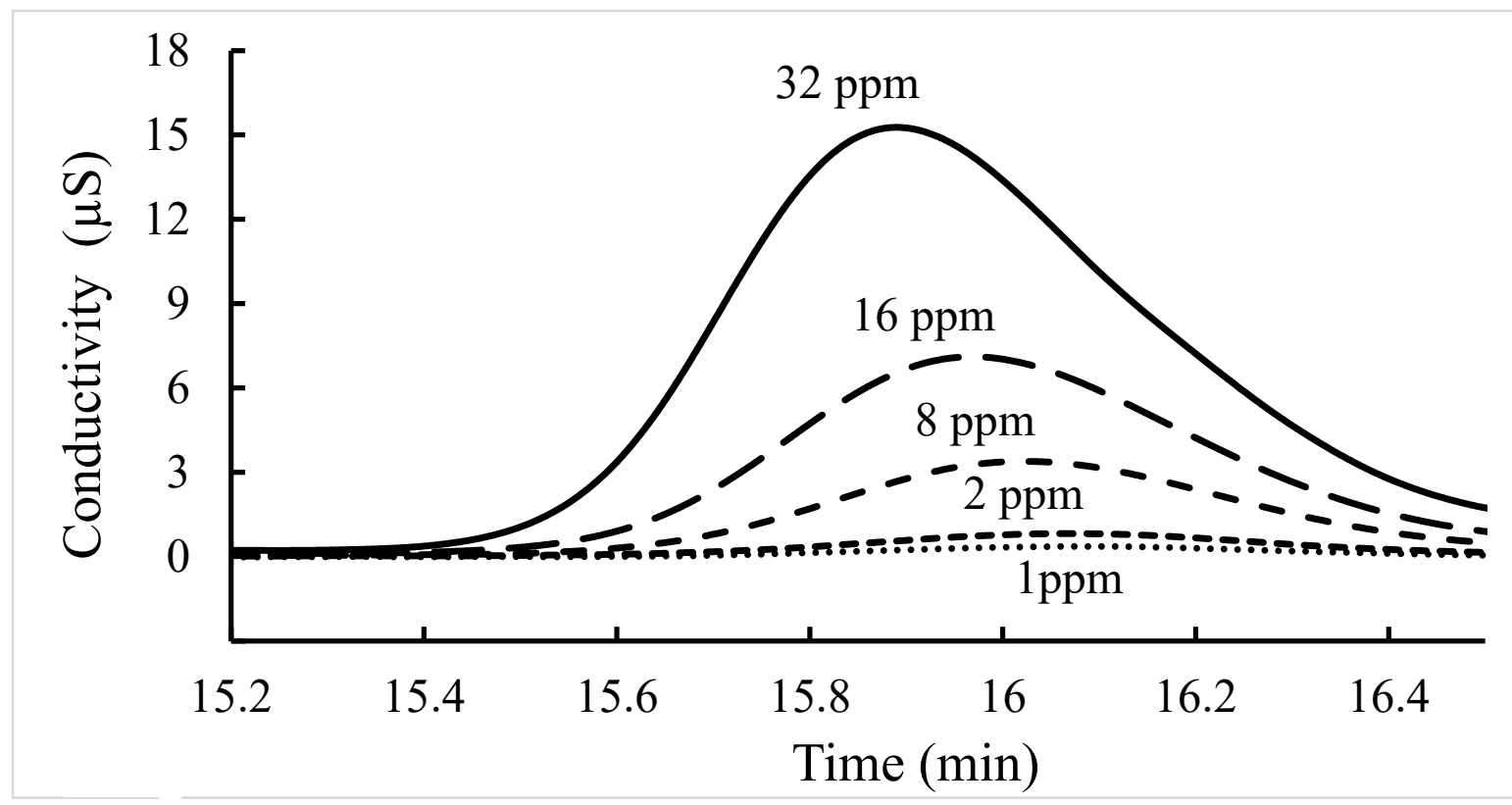

Figure S1: A typical set of digital signal data from the standard calibration of phosphate measured as conductivity using the Thermo Scientific Dionex ion chromatography system. The standards were prepared to make concentrations in a range from $1 \mathrm{mg} / \mathrm{L}(1 \mathrm{ppm})$ to $32 \mathrm{mg} / \mathrm{L}(32 \mathrm{ppm})$. The peak of phosphate appeared at a retention time between $15.4 \mathrm{~min}$ to $16.4 \mathrm{~min}$. The area under each curve is correlated to the concentration of phosphate. The area was converted to phosphate concentration and the resulting equation was used determine the phosphate concentration of the samples. 


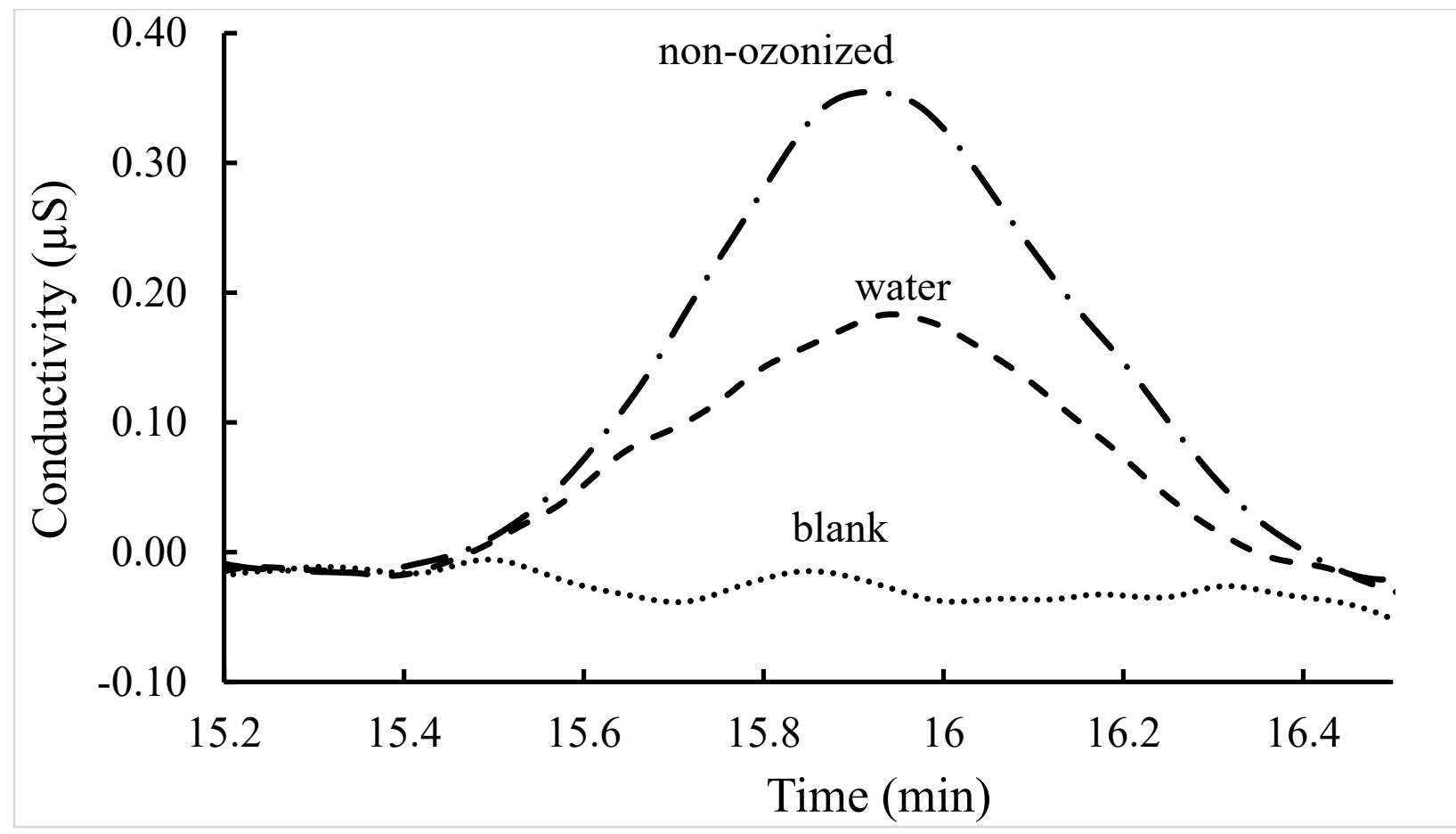

Figure S2: A typical set of digital signal data on phosphate concentration measured as conductivity using the Thermo Scientific Dionex ion chromatography system. The phosphate peak marked with "nonozonized" is from the incubation of the non-ozonized biochar and its filtrate and hydroxyapatite after $30 \mathrm{~min}$. The phosphate peak marked with "water" is from the incubation of water and hydroxyapatite after $30 \mathrm{~min}$. The baseline marked as "blank" is from Millipore water only. Note that the phosphate peak marked with "non-ozonized" in this figure were not only from the hydroxyapatite but also from the biochar. For the water phosphate peak marked with "water", the phosphate apparently came from the hydroxyapatite since the blank (Millipore water only) baseline showed no peak. The set-up is shown in $5^{\text {th }}$ row of Table S2. Integration for the area under the curve is useful to calculate the phosphate concentrations. 


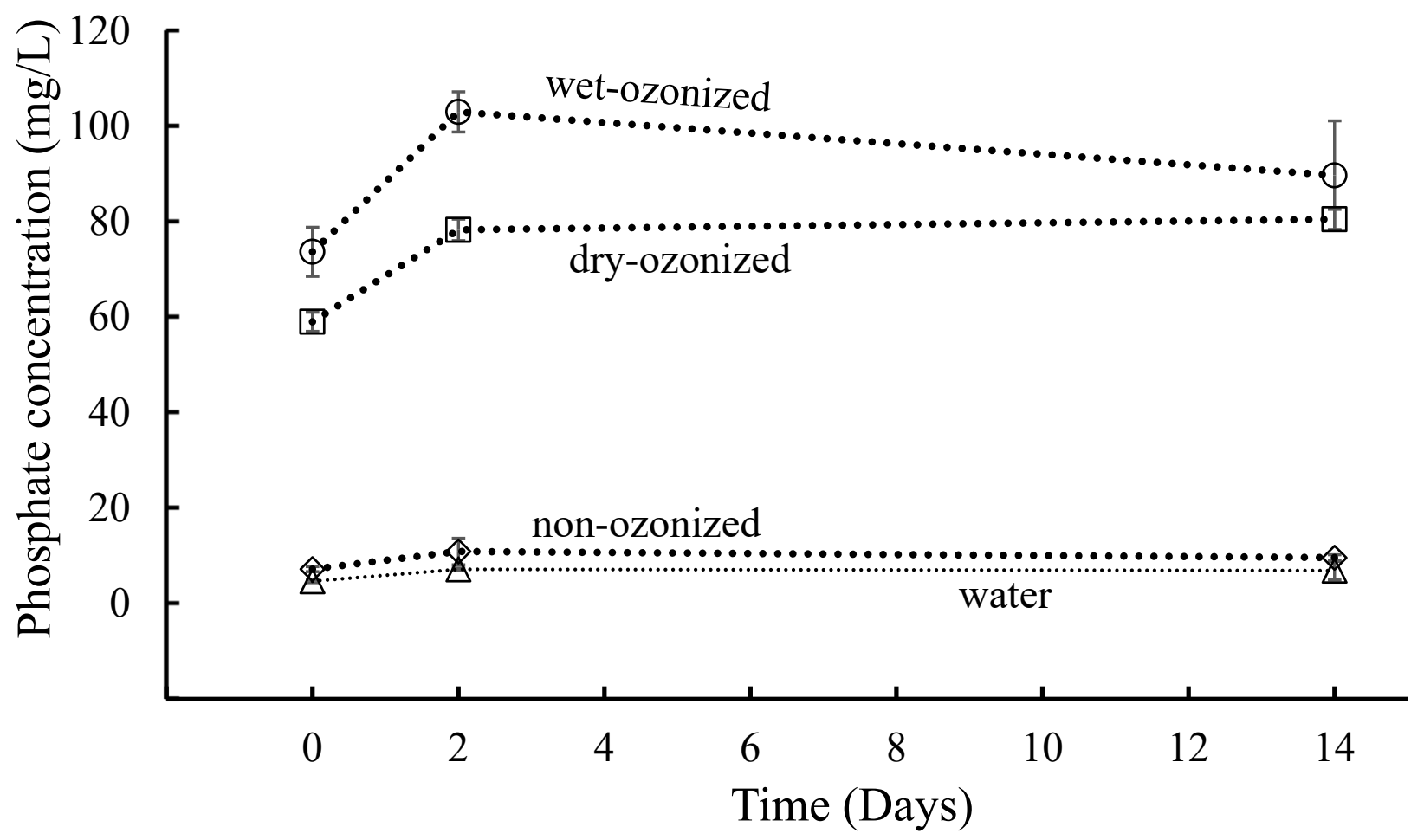

Figure S3: Solubilized phosphate concentration determined in the liquid samples from the mixture of biochar, water and hydroxyapatite during the hydroxyapatite assays. The set-up is shown in $2^{\text {nd }}$ row of Table $\mathrm{S} 2$. The concentrations represented are the corrected concentration values; the phosphate that came from the biochar (shown in Table S3) was subtracted from the total phosphate concentration upon the addition of hydroxyapatite therefore the values shown in this figure are solely from the hydroxyapatite. In this assay there was no filtrate added because the purpose was to determine the effect of the biochar and the functional groups on its surface in solubilizing phosphate from hydroxyapatite. The phosphate from the hydroxyapatite that was incubated with the non-ozonized biochar appeared to the lowest. The phosphate from the hydroxyapatite that was incubated with the wet-ozonized biochar appeared to be the highest. Each measurement point is the average of 3 replicates $\pm S D(n=3)$. For numerical values, see Table $S 4$. 


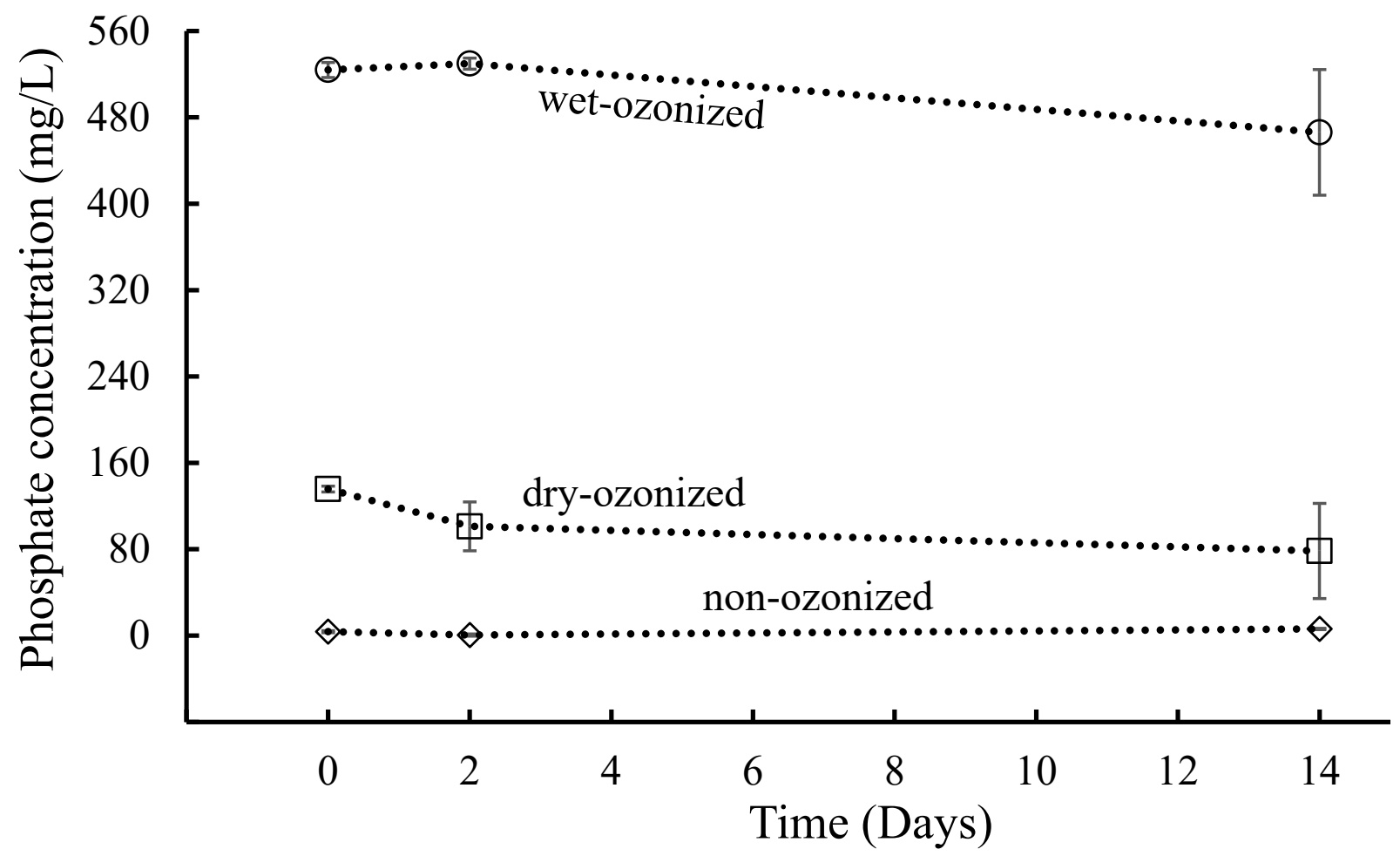

Figure S4: Solubilized phosphate concentration measured in the incubation liquid of hydroxyapatite and biochar filtrate only (no biochar solid material). The biochar was omitted here to determine whether the biochar solid material is necessary or not for solubilizing phosphate from hydroxyapatite. The set-up is shown in $4^{\text {th }}$ row of Table S2. The concentrations represented are the corrected concentration values; the phosphate that came from the filtrate of the biochar (shown in Table S3) was subtracted from the total phosphate concentration upon the addition of hydroxyapatite; therefore the values shown are solely from the hydroxyapatite. The phosphate from the hydroxyapatite incubated with the filtrate of the non-ozonized biochar was barely detectable. The phosphate from the hydroxyapatite incubated with the filtrate of the wet-ozonized biochar appeared to be the highest among all. After 14 days of incubation, there is a slight drop in phosphate concentration for the wet-ozonized and dry-ozonized samples but not the non-ozonized sample. Each measurement point is the average of 3 replicates $\pm S D(n=3)$. For numerical values, see Table $S 4$. 


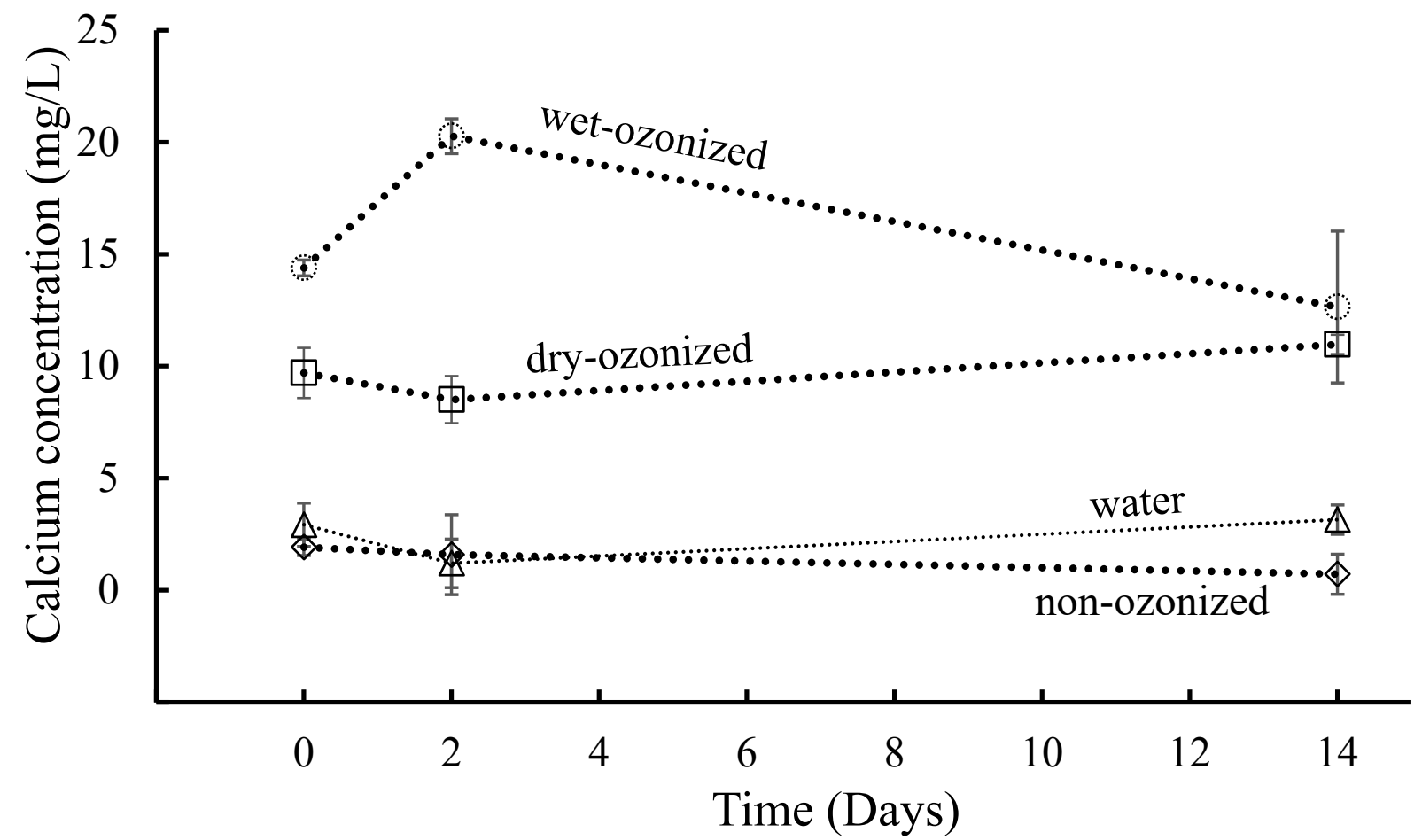

Figure S5: Solubilized Calcium concentration measured in the incubation liquid of hydroxyapatite with biochar (no filtrate) and water. The set-up is shown in $2^{\text {nd }}$ row of Table S2. The Ca concentrations represented are the corrected concentration values for $\mathrm{Ca}$ from hydroxyapatite solubilization only; the calcium that came from the biochar (shown in Table S3) was subtracted from the total calcium concentration upon the addition of hydroxyapatite. Therefore, the values shown in this figure are solely from the hydroxyapatite. In this assay there was no filtrate added because the purpose was to determine the effect of the biochar and the functional groups on its surface in solubilizing calcium from hydroxyapatite. The calcium from the hydroxyapatite incubated with the non-ozonized biochar appeared to be the lowest. The calcium from the hydroxyapatite incubated with the wet-ozonized biochar appeared to be the highest. Each measurement point is the average of 3 replicates $\pm \mathrm{SD}(\mathrm{n}=3)$. For numerical values, see Table S4. 


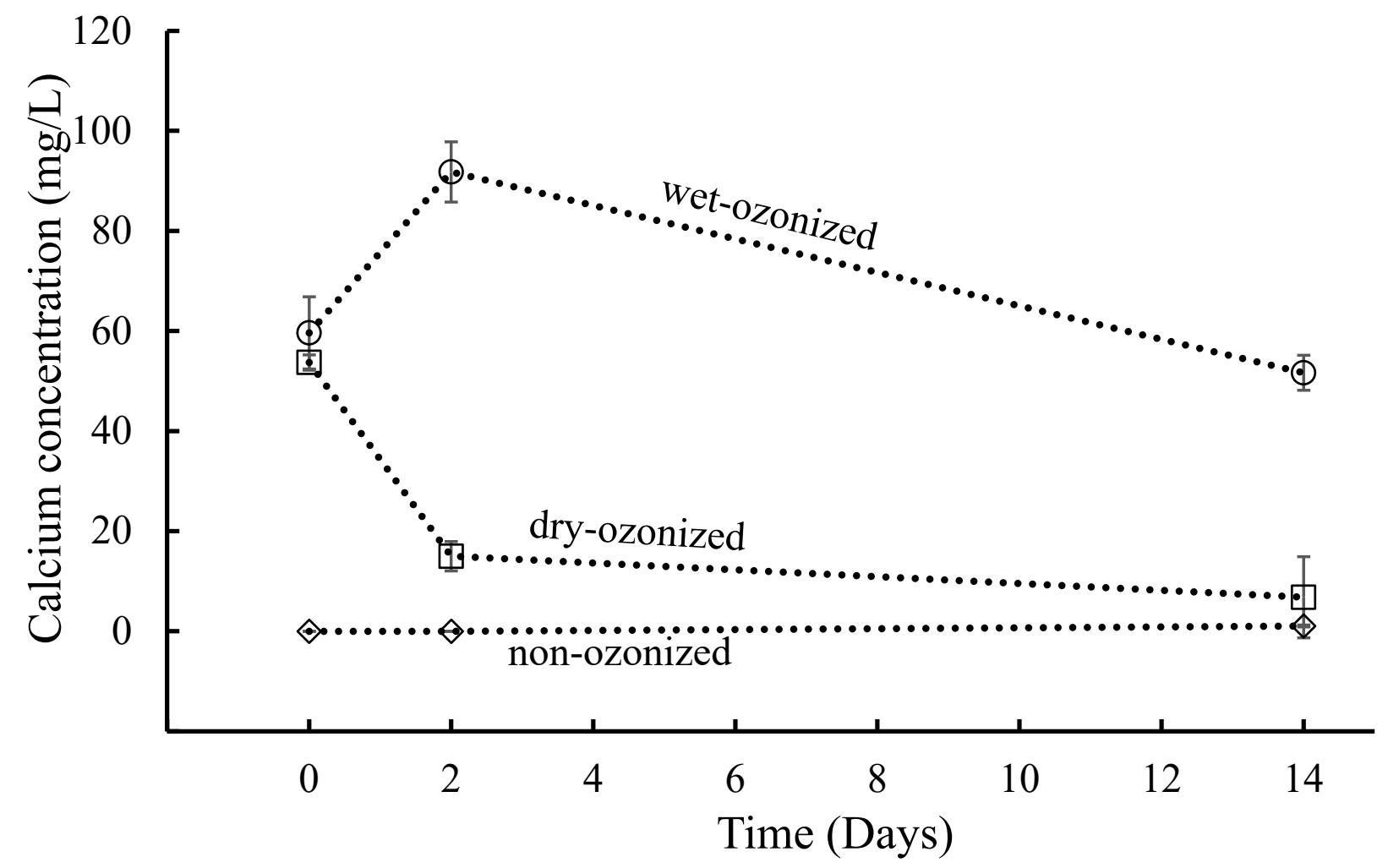

Figure S6: Solubilized Calcium concentration measured in the incubation liquid of hydroxyapatite with biochar filtrate (no solid biochar material). The set-up is shown in $4^{\text {th }}$ row of Table S2. The biochar was omitted in order to determine whether the latter is necessary or not for solubilizing calcium from hydroxyapatite. The concentrations represented are the corrected concentration values; the calcium that came from the filtrate of the biochar (shown in Table S3) was subtracted from the total calcium concentration upon the addition of hydroxyapatite. Therefore the values shown are solely from the hydroxyapatite. The calcium from the hydroxyapatite that was incubated with the non-ozonized biochar was barely detectable. The calcium from the hydroxyapatite that was incubated with the wet-ozonized biochar appeared to be the highest out of all. After 14 days of incubation, there is a drop in calcium concentration. Each measurement point is the average of 3 replicates $\pm \mathrm{SD}(\mathrm{n}=3)$. For numerical values, see Table S4. 


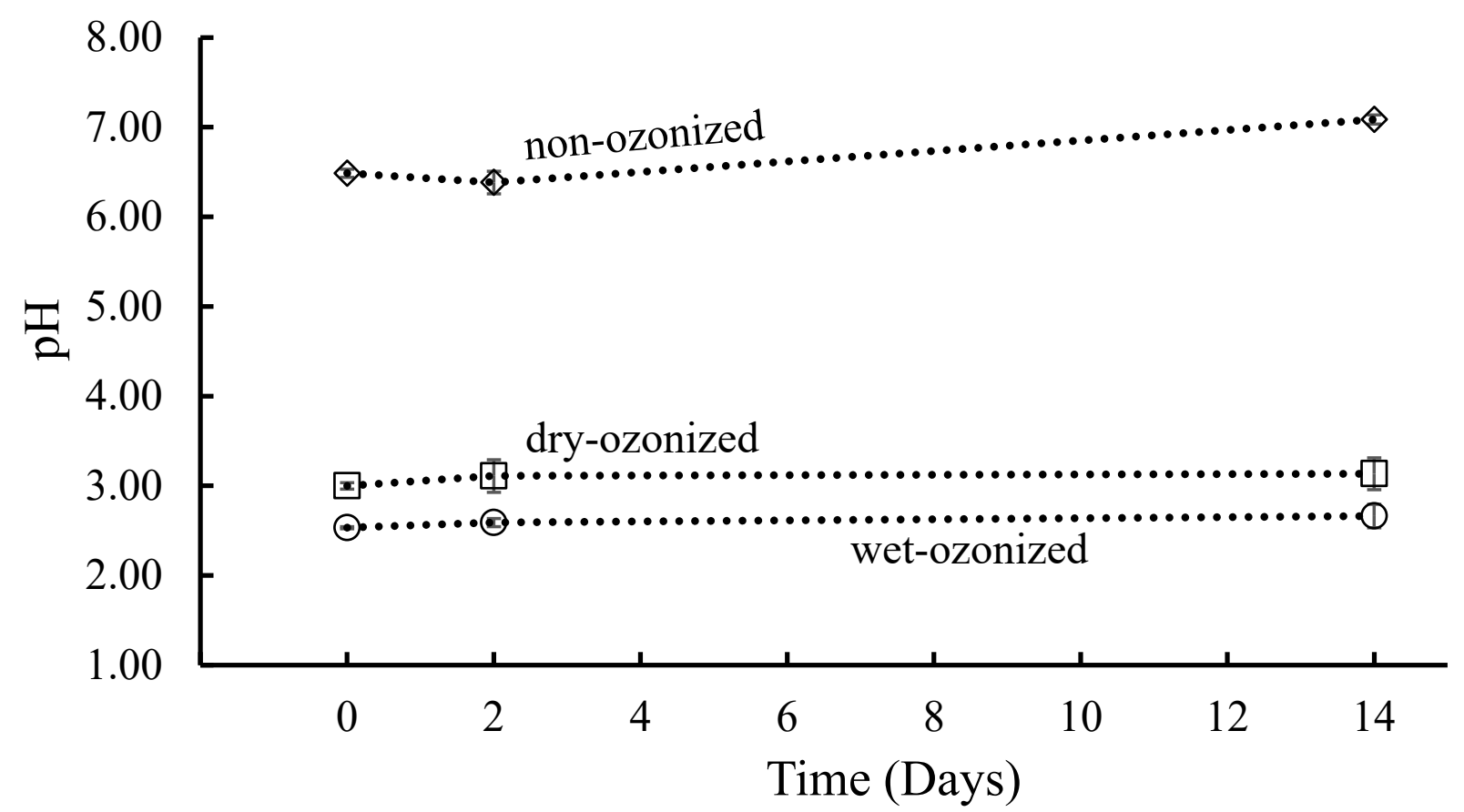

Figure S7: $\mathrm{pH}$ of the filtrates from the different types of biochar after $30 \mathrm{~min}$ (represented as day 0), 2 days and 14 days. The set-up is shown in $3^{\text {rd }}$ row of Table S2. The filtrate of the wash of the non-ozonized biochar had the highest $\mathrm{pH}$. The filtrate of the wet-ozonized biochar appeared to be the most acidic. The filtrate of the wash of the dry ozonized biochar also had a very low $\mathrm{pH}$. From day 0 to day 14, the $\mathrm{pH}$ got a slightly more basic for all filtrates but not a significant change. Those $\mathrm{pH}$ measurements showed that ozone treatment had an effect on the biochar. The figure also provides information of the initial $\mathrm{pH}$ before the addition of hydroxyapatite. Each measurement point is the average of 3 replicates $\pm \mathrm{SD}(\mathrm{n}=3)$. For $\mathrm{pH}$ numerical values, see Table S3. 


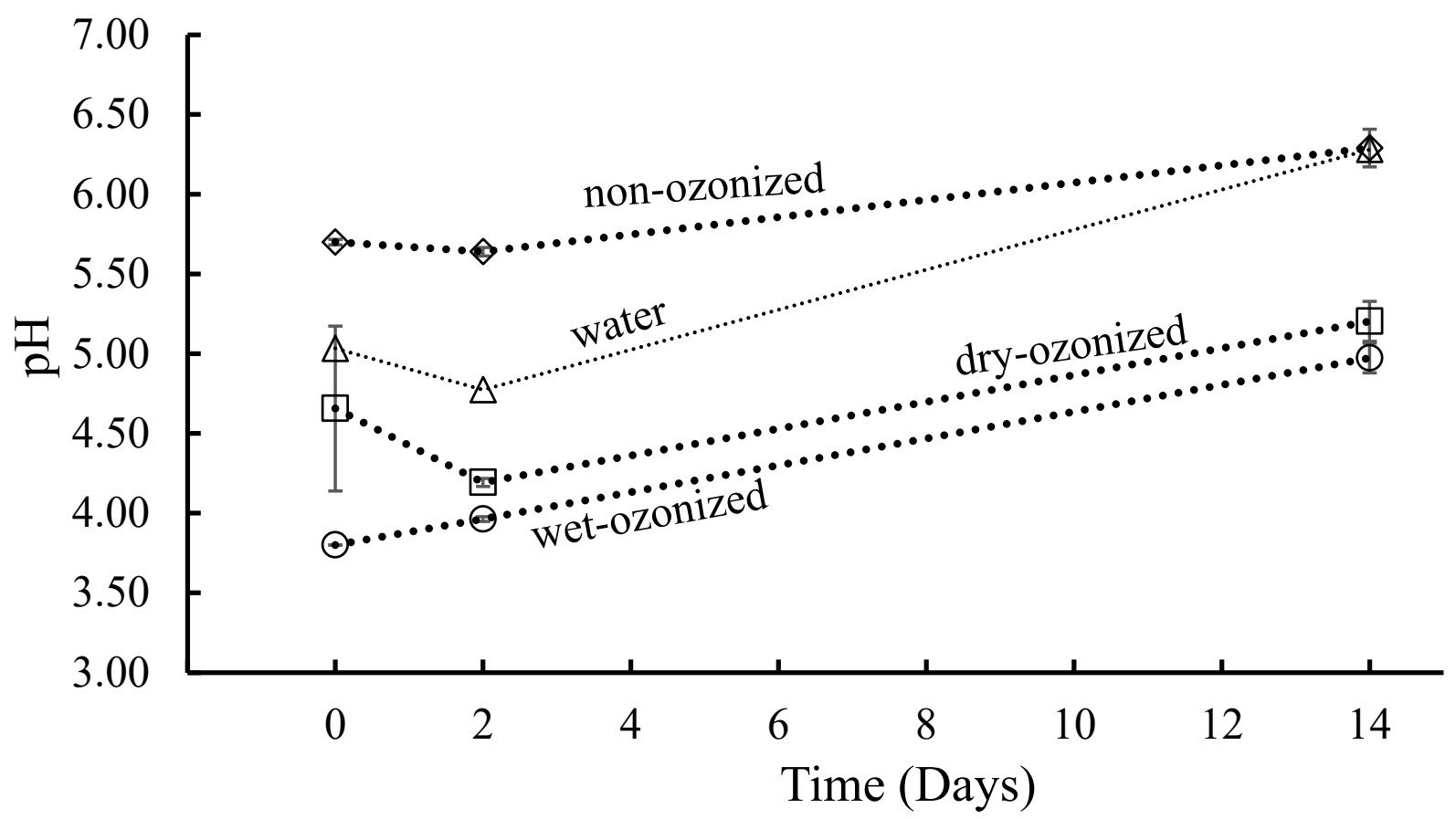

Figure S8: $\mathrm{pH}$ of different types of biochar when mixed with water after $30 \mathrm{~min}$ (represented as day 0), 2 days and 14 days. The set-up is shown in $1^{\text {st }}$ row of Table S2. In the hydroxyapatite assay, as another control, the biochars were incubated with water. This control provided information on the initial $\mathrm{pH}$ of the biochar in the liquid medium before the addition of hydroxyapatite. The non-ozonized biochar had the least acidic $\mathrm{pH}$ at 30min, 2 days and 14 days after shaking. The wet-ozonized biochar showed a very acidic $\mathrm{pH}$ after $30 \mathrm{~min}$ of shaking and still had the lowest $\mathrm{pH}$ after 14 days of shaking. The Millipore water control appeared initially at a $\mathrm{pH}$ of 5.03 and then increased to 6.28 . This $\mathrm{pH}$ fluctuation may be due to the release of $\mathrm{CO}_{2}$ from the water. A slight increase in $\mathrm{pH}$ was observed for the biochar samples; it may be due to the uptake and release of $\mathrm{CO}_{2}$ from the liquid as well as the release of the ashes from the biochar over time. Each measurement point is the average of 3 replicates $\pm \mathrm{SD}(\mathrm{n}=3)$. For $\mathrm{pH}$ numerical values, see Table $\mathrm{S} 3$. 


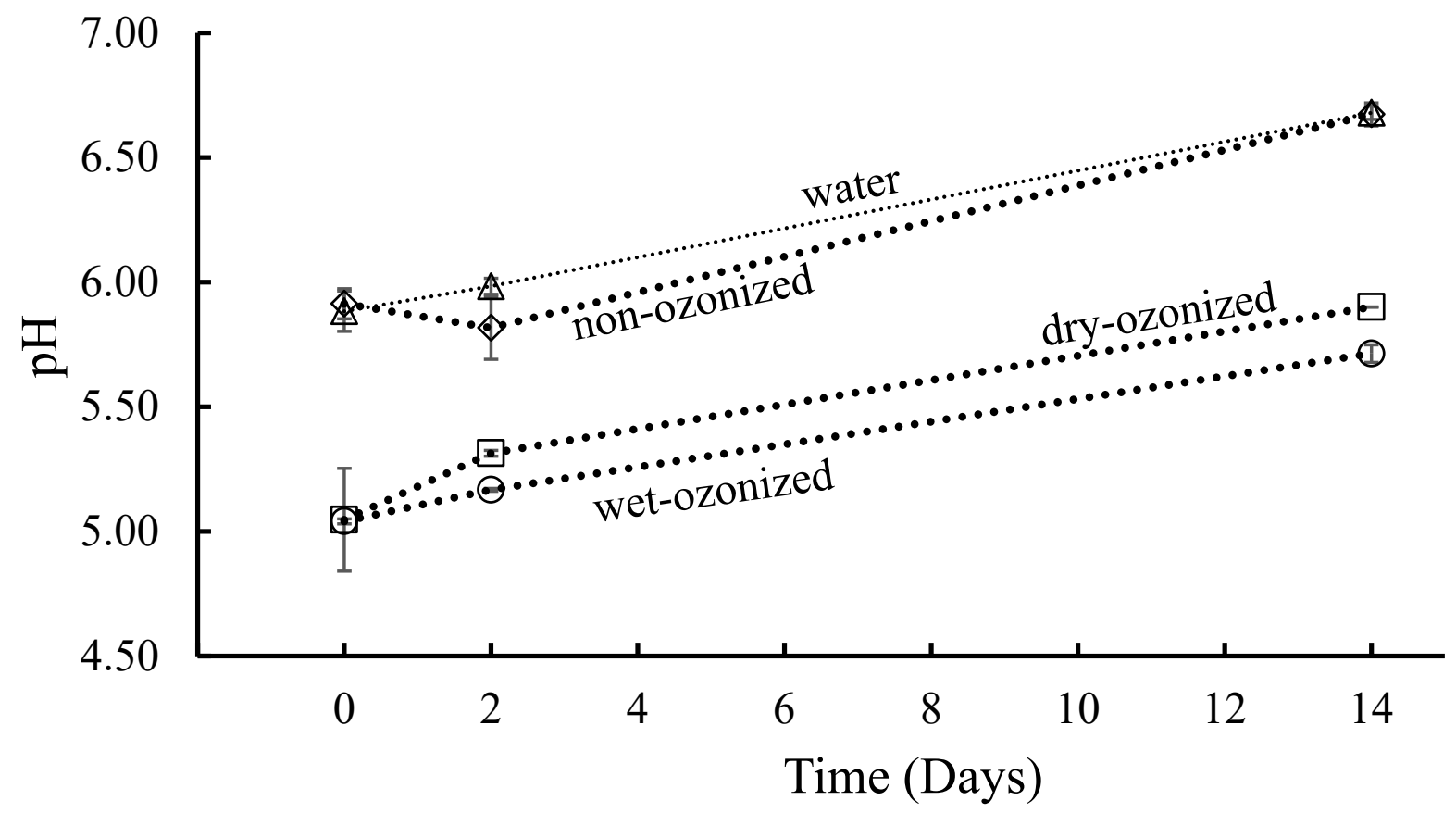

Figure S9: $\mathrm{pH}$ of the liquid samples from the mixture of biochar, water and hydroxyapatite after $30 \mathrm{~min}$ (represented as day 0), 2 days and 14 days during the hydroxyapatite assay. The set-up is shown in $2^{\text {nd }}$ row of Table S2. In this assay, the biochars that were used had been washed and dried in oven before being remixed with hydroxyapatite and water. In this assay there was no filtrate added because the purpose was to determine the effect of the biochar and the functional groups on its surface and not the filtrate. The $\mathrm{pH}$ of the non-ozonized biochar was the least acidic. The $\mathrm{pH}$ of the wet-ozonized biochar and the dry-ozonized biochar were the most acidic. For all the samples, over time the $\mathrm{pH}$ became slightly more basic $(0.5 \mathrm{pH}$ unit increase) after 14 days of incubation. It may be due to the release of $\mathrm{CO}_{2}$ from the liquid as well as the release of the ashes from the biochar over time. In addition, the $\mathrm{pH}$ increase may also be due to the solubilization of hydroxyapatite. Each measurement point is the average of 3 replicates $\pm \mathrm{SD}(\mathrm{n}=3)$. For pH numerical values, see Table S4. 


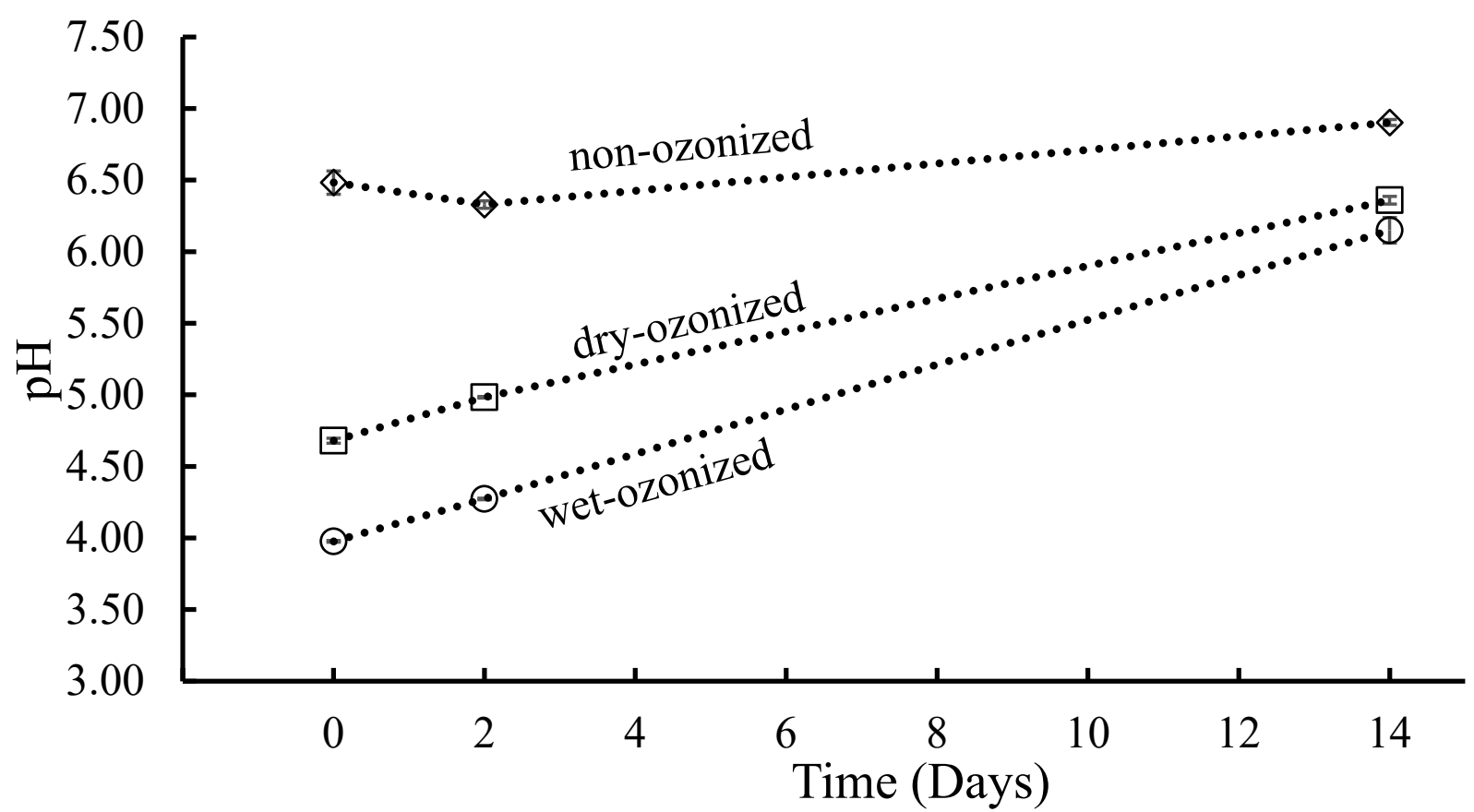

Figure S10: $\mathrm{pH}$ of the liquid samples from the mixture of biochar filtrate and hydroxyapatite as measured during the hydroxyapatite assay. The set-up is shown in $4^{\text {th }}$ row of Table S2. The purpose of omitting the biochar was to determine whether or not the biochar is necessary for causing a $\mathrm{pH}$ change in the solubilization assay of the hydroxyapatite. The $\mathrm{pH}$ of the non-ozonized biochar was the least acidic. The $\mathrm{pH}$ of the wet-ozonized biochar was the most acidic. For all the samples, over time the $\mathrm{pH}$ became more basic $(2 \mathrm{pH}$ unit increase for the wet-ozonized and $1.5 \mathrm{pH}$ unit increase for the dry ozonized assays after 2 weeks.) The $\mathrm{pH}$ increase here may be due to the release of $\mathrm{CO}_{2}$ from the liquid but majorly to the solubilization of hydroxyapatite. Each measurement point is the average of 3 replicates $\pm \mathrm{SD}(\mathrm{n}=3)$. For $\mathrm{pH}$ numerical values, see Table S4.

Table S3: The phosphate and calcium and $\mathrm{pH}$ of the biochar and its filtrate (without adding the hydroxyapatite) as measured after incubation for $30 \mathrm{~min}, 2$ days and 14 days. Experimental set-up is shown in row 1 and 3 of Table S2. Note, the phosphate concentration measurement of the no biochar control (pure water only) represents the instrument baseline signal (not true phosphate concentration). The data shown in this table were not baseline corrected. Each measurement is the average of 3 replicates $\pm \mathrm{SD}(\mathrm{n}=3)$.

\begin{tabular}{|c|c|c|c|}
\hline \multirow{2}{*}{} & \multicolumn{3}{|c|}{ Phosphate concentration from Biochar and its filtrate } \\
\cline { 2 - 4 } & $30 \mathrm{~min}$ & 2 days & 14 days \\
\cline { 2 - 4 } & $\begin{array}{c}\text { Concentration } \\
(\mathrm{mg} / \mathrm{L})\end{array}$ & $\begin{array}{c}\text { Concentration } \\
(\mathrm{mg} / \mathrm{L})\end{array}$ & $\begin{array}{c}\text { Concentration } \\
(\mathrm{mg} / \mathrm{L})\end{array}$ \\
\hline $\begin{array}{c}\text { non-ozonized biochar }+ \\
\text { water }\end{array}$ & $7.001 \pm 0$ & $9.840 \pm 1.020$ & $8.432 \pm 0.690$ \\
\hline $\begin{array}{c}\text { wet-ozonized biochar }+ \\
\text { water }\end{array}$ & $7.161 \pm 0.277$ & $11.89 \pm 1.92$ & $14.47 \pm 6.87$ \\
\hline
\end{tabular}




\begin{tabular}{|c|c|c|c|}
\hline $\begin{array}{l}\text { dry-ozonized biochar }+ \\
\text { water }\end{array}$ & $7.348 \pm 0.303$ & $7.628 \pm 1.085$ & $7.455 \pm 0.163$ \\
\hline $\begin{array}{l}\text { No biochar control (water } \\
\text { only) }\end{array}$ & $7.001 \pm 0$ & $7.001 \pm 0$ & $6.708 \pm 1.290$ \\
\hline $\begin{array}{c}\text { non-ozonized biochar } \\
\text { filtrate }\end{array}$ & $8.121 \pm 0.999$ & $14.05 \pm 4.39$ & $6.148 \pm 0.287$ \\
\hline $\begin{array}{l}\text { wet-ozonized biochar } \\
\text { filtrate }\end{array}$ & $12.49 \pm 0.42$ & $42.49 \pm 19.17$ & $110.4 \pm 49.6$ \\
\hline \multirow[t]{4}{*}{$\begin{array}{l}\text { dry-ozonized biochar } \\
\text { filtrate } \\
\end{array}$} & $8.187 \pm 1.032$ & $40.46 \pm 22.01$ & $52.12 \pm 43.01$ \\
\hline & \multicolumn{3}{|c|}{ Calcium concentration from Biochar and its filtrate } \\
\hline & $30 \mathrm{~min}$ & 2 days & 14 days \\
\hline & $\begin{array}{c}\text { Concentration } \\
(\mathrm{mg} / \mathrm{L})\end{array}$ & $\begin{array}{c}\text { Concentration } \\
(\mathrm{mg} / \mathrm{L})\end{array}$ & $\begin{array}{c}\text { Concentration } \\
(\mathrm{mg} / \mathrm{L}) \\
\end{array}$ \\
\hline $\begin{array}{l}\text { non-ozonized biochar }+ \\
\text { water }\end{array}$ & $2.679 \pm 0.117$ & $4.015 \pm 1.032$ & $2.017 \pm 0.465$ \\
\hline $\begin{array}{l}\text { wet-ozonized biochar }+ \\
\text { water }\end{array}$ & 0 & $4.969 \pm 1.485$ & $3.390 \pm 3.167$ \\
\hline $\begin{array}{l}\text { dry-ozonized biochar }+ \\
\text { water }\end{array}$ & 0 & $7.781 \pm 2.469$ & $1.992 \pm 0.338$ \\
\hline $\begin{array}{c}\text { No biochar control (water } \\
\text { only) }\end{array}$ & 0 & 0 & 0 \\
\hline $\begin{array}{l}\text { non-ozonized biochar } \\
\text { filtrate }\end{array}$ & $1.064 \pm 0.052$ & $2.145 \pm 1.524$ & 0 \\
\hline $\begin{array}{l}\text { wet-ozonized biochar } \\
\text { filtrate }\end{array}$ & $27.18 \pm 3.54$ & $38.72 \pm 4.75$ & $33.58 \pm 4.02$ \\
\hline \multirow[t]{4}{*}{$\begin{array}{l}\text { dry-ozonized biochar } \\
\text { filtrate } \\
\end{array}$} & $5.145 \pm 1.101$ & $21.64 \pm 6.02$ & $26.18 \pm 9.15$ \\
\hline & \multicolumn{3}{|c|}{ pH } \\
\hline & $30 \mathrm{~min}$ & 2 days & 14 days \\
\hline & $\mathrm{pH}$ & $\mathrm{pH}$ & $\mathrm{pH}$ \\
\hline $\begin{array}{l}\text { non-ozonized biochar }+ \\
\text { water }\end{array}$ & $5.70 \pm 0.02$ & $5.64 \pm 0.03$ & $6.29 \pm 0.12$ \\
\hline $\begin{array}{l}\text { wet-ozonized biochar }+ \\
\text { water }\end{array}$ & $3.80 \pm 0$ & $3.96 \pm 0.02$ & $4.97 \pm 0.09$ \\
\hline $\begin{array}{l}\text { dry-ozonized biochar }+ \\
\text { water }\end{array}$ & $4.66 \pm 0.52$ & $4.19 \pm 0.03$ & $5.20 \pm 0.13$ \\
\hline $\begin{array}{c}\text { No biochar control (water } \\
\text { only) }\end{array}$ & $5.03 \pm 0.07$ & $4.77 \pm 0.28$ & $6.28 \pm 0.40$ \\
\hline $\begin{array}{l}\text { non-ozonized biochar } \\
\text { filtrate }\end{array}$ & $6.49 \pm 0.05$ & $6.38 \pm 0.13$ & $7.09 \pm 0.05$ \\
\hline $\begin{array}{l}\text { wet-ozonized biochar } \\
\text { filtrate }\end{array}$ & $2.53 \pm 0.01$ & $2.59 \pm 0.05$ & $2.66 \pm 0.13$ \\
\hline
\end{tabular}


dry-ozonized biochar

filtrate
$3.00 \pm 0.04$
$3.11 \pm 0.18$

$3.14 \pm 0.17$

Table S4: Experimental data on the concentration of phosphate and calcium from the hydroxyapatite and $\mathrm{pH}$ measurements for the hydroxyapatite assay. The data is shown for $30 \mathrm{~min}, 2$ days and 14 days of incubation. Set-up shown in row 2, 4 and 5 of Table S2. The data shown here are the corrected data and were obtained by subtracting the phosphate and calcium that resulted from biochar and/or its filtrate from the total phosphate and calcium upon addition of hydroxyapatite. Each measurement is the average of 3 replicates $\pm \mathrm{SD}(\mathrm{n}=3)$. Note: HA stands for Hydroxyapatite.

\begin{tabular}{|c|c|c|c|}
\hline & \multicolumn{3}{|c|}{ Phosphate concentration from Hydroxyapatite } \\
\hline & $30 \mathrm{~min}$ & 2 days & 14 days \\
\hline & $\begin{array}{l}\text { Concentration } \\
(\mathrm{mg} / \mathrm{L})\end{array}$ & $\begin{array}{c}\text { Concentration } \\
(\mathrm{mg} / \mathrm{L})\end{array}$ & $\begin{array}{c}\text { Concentration } \\
(\mathrm{mg} / \mathrm{L})\end{array}$ \\
\hline $\begin{array}{c}\text { non-ozonized biochar }+ \text { water }+ \\
\text { HA }\end{array}$ & $7.210 \pm 0.514$ & $10.90 \pm 2.77$ & $9.612 \pm 0.608$ \\
\hline $\begin{array}{c}\text { wet-ozonized biochar }+ \text { water }+ \\
\text { HA } \\
\end{array}$ & $73.73 \pm 5.14$ & $103.0 \pm 4.2$ & $89.73 \pm 11.46$ \\
\hline $\begin{array}{c}\text { dry-ozonized biochar }+ \text { water }+ \\
\text { HA }\end{array}$ & $59.04 \pm 2.00$ & $78.31 \pm 2.25$ & $80.52 \pm 2.09$ \\
\hline $\begin{array}{c}\text { No Biochar control (water + HA } \\
\text { only) }\end{array}$ & $4.678 \pm 0.3123$ & $7.170 \pm 0.257$ & $6.897 \pm 1.958$ \\
\hline $\begin{array}{c}\text { non-ozonized biochar \& its filtrate } \\
+ \text { HA }\end{array}$ & $0.2906 \pm 0.2640$ & $0.145 \pm 0.252$ & $3.766 \pm 1.336$ \\
\hline $\begin{array}{c}\text { wet-ozonized biochar \& its filtrate } \\
\text { + HA }\end{array}$ & $553.1 \pm 12.8$ & $569.9 \pm 6.4$ & $553.7 \pm 55.2$ \\
\hline $\begin{array}{c}\text { dry-ozonized biochar \& its filtrate } \\
+ \text { HA }\end{array}$ & $168.8 \pm 10.8$ & $165.9 \pm 16.9$ & $140.0 \pm 39.2$ \\
\hline $\begin{array}{c}\text { non-ozonized biochar filtrate }+ \\
\text { HA } \\
\end{array}$ & $3.705 \pm 0.920$ & $0.600 \pm 1.038$ & $6.193 \pm 0.574$ \\
\hline $\begin{array}{c}\text { wet-ozonized biochar filtrate }+ \\
\text { HA }\end{array}$ & $524.0 \pm 7.0$ & $529.9 \pm 5.2$ & $466.2 \pm 58.3$ \\
\hline \multirow[t]{4}{*}{$\begin{array}{c}\text { dry-ozonized biochar filtrate }+ \\
\text { HA } \\
\end{array}$} & $135.8 \pm 2.7$ & $101.2 \pm 22.6$ & $78.49 \pm 44.08$ \\
\hline & \multicolumn{3}{|c|}{ Calcium concentration from Hydroxyapatite } \\
\hline & $30 \mathrm{~min}$ & 2 days & 14 days \\
\hline & $\begin{array}{c}\text { Concentration } \\
(\mathrm{mg} / \mathrm{L})\end{array}$ & $\begin{array}{c}\text { Concentration } \\
(\mathrm{mg} / \mathrm{L})\end{array}$ & $\begin{array}{c}\text { Concentration } \\
(\mathrm{mg} / \mathrm{L})\end{array}$ \\
\hline $\begin{array}{c}\text { non-ozonized biochar }+ \text { water }+ \\
\text { HA }\end{array}$ & $1.922 \pm 0.372$ & $1.588 \pm 1.784$ & $0.717 \pm 0.895$ \\
\hline $\begin{array}{c}\text { wet-ozonized biochar }+ \text { water }+ \\
\text { HA }\end{array}$ & $14.39 \pm 0.35$ & $20.27 \pm 0.78$ & $12.64 \pm 3.39$ \\
\hline
\end{tabular}




\begin{tabular}{|c|c|c|c|}
\hline $\begin{array}{c}\text { dry-ozonized biochar + water }+ \\
\text { HA }\end{array}$ & $9.702 \pm 1.122$ & $8.510 \pm 1.051$ & $10.97 \pm 0.43$ \\
\hline $\begin{array}{c}\text { No Biochar control (water + HA } \\
\text { only) }\end{array}$ & $2.922 \pm 0.967$ & $1.203 \pm 1.086$ & $3.155 \pm 0.653$ \\
\hline $\begin{array}{c}\text { non-ozonized biochar \& its filtrate } \\
+\mathrm{HA}\end{array}$ & 0.000 & $0.448 \pm 0.775$ & $0.339 \pm 0.137$ \\
\hline $\begin{array}{c}\text { wet-ozonized biochar \& its filtrate } \\
\text { + HA }\end{array}$ & $58.84 \pm 5.26$ & $66.02 \pm 4.16$ & $33.50 \pm 7.10$ \\
\hline $\begin{array}{c}\text { dry-ozonized biochar \& its filtrate } \\
+\mathrm{HA}\end{array}$ & 0 & $8.452 \pm 4.819$ & $6.278 \pm 8.001$ \\
\hline $\begin{array}{c}\text { non-ozonized biochar filtrate }+ \\
\text { HA }\end{array}$ & 0 & 0 & $1.053 \pm 0.188$ \\
\hline $\begin{array}{c}\text { wet-ozonized biochar filtrate }+ \\
\text { HA }\end{array}$ & $59.63 \pm 7.22$ & $91.80 \pm 6.02$ & $51.66 \pm 3.50$ \\
\hline \multirow[t]{4}{*}{$\begin{array}{c}\text { dry-ozonized biochar filtrate }+ \\
\text { HA } \\
\end{array}$} & $53.71 \pm 1.53$ & $15.00 \pm 2.93$ & $6.798 \pm 8.108$ \\
\hline & \multicolumn{3}{|c|}{ pH } \\
\hline & $30 \mathrm{~min}$ & 2 days & 14 days \\
\hline & $\mathrm{pH}$ & $\mathrm{pH}$ & $\mathrm{pH}$ \\
\hline $\begin{array}{l}\text { non-ozonized biochar }+ \text { water }+ \\
\text { HA }\end{array}$ & $5.91 \pm 0.06$ & $5.64 \pm 0.13$ & $6.67 \pm 0.05$ \\
\hline $\begin{array}{l}\text { wet-ozonized biochar + water + } \\
\text { HA }\end{array}$ & $5.04 \pm 0.01$ & $3.96 \pm 0.01$ & $5.71 \pm 0.04$ \\
\hline $\begin{array}{l}\text { dry-ozonized biochar }+ \text { water }+ \\
\text { HA }\end{array}$ & $5.05 \pm 0.21$ & $4.19 \pm 0.01$ & $5.90 \pm 0.00$ \\
\hline \begin{tabular}{|c|}
$\begin{array}{c}\text { No Biochar control (water + HA } \\
\text { only) }\end{array}$ \\
\end{tabular} & $5.88 \pm 0.08$ & $4.77 \pm 0.03$ & $6.68 \pm 0.03$ \\
\hline $\begin{array}{c}\text { non-ozonized biochar \& its filtrate } \\
\text { + HA }\end{array}$ & $5.98 \pm 0.02$ & $5.81 \pm 0.01$ & $6.79 \pm 0.05$ \\
\hline $\begin{array}{c}\begin{array}{c}\text { wet-ozonized biochar \& its filtrate } \\
\text { + HA }\end{array} \\
\end{array}$ & $3.97 \pm 0.00$ & $4.28 \pm 0.00$ & $5.72 \pm 0.01$ \\
\hline $\begin{array}{c}\text { dry-ozonized biochar \& its filtrate } \\
+\mathrm{HA}\end{array}$ & $4.63 \pm 0.03$ & $4.83 \pm 0.01$ & $6.17 \pm 0.01$ \\
\hline $\begin{array}{c}\text { non-ozonized biochar filtrate }+ \\
\text { HA }\end{array}$ & $6.48 \pm 0.08$ & $6.33 \pm 0.03$ & $6.90 \pm 0.02$ \\
\hline $\begin{array}{c}\text { wet-ozonized biochar filtrate }+ \\
\text { HA }\end{array}$ & $3.98 \pm 0.01$ & $4.27 \pm 0.01$ & $6.15 \pm 0.09$ \\
\hline $\begin{array}{c}\text { dry-ozonized biochar filtrate }+ \\
\text { HA } \\
\end{array}$ & $4.68 \pm 0.02$ & $4.98 \pm 0.01$ & $6.36 \pm 0.03$ \\
\hline
\end{tabular}


Table S5: Experimental data on the concentration of phosphorus measured during the hydroxyapatite assay. The data is shown for 30min, 2 days and 14 days of incubation. Set-up shown in row 2, 4 and 5 of Table S2. In order to get the phosphorus concentration, the phosphate concentration was converted to phosphorus by multiplying it by (30.97376/94.9714). The data shown here are the corrected data and were obtained by subtracting the phosphorus from biochar and/or its filtrate. Each measurement is the average of 3 replicates $\pm \mathrm{SD}(\mathrm{n}=3)$. Note: HA stands for Hydroxyapatite.

\begin{tabular}{|c|c|c|c|}
\hline & \multicolumn{3}{|c|}{ Phosphorus concentration from Hydroxyapatite } \\
\hline & $30 \mathrm{~min}$ & 2 days & 14 days \\
\hline & $\begin{array}{c}\text { Concentration } \\
(\mathrm{mg} / \mathrm{L})\end{array}$ & $\begin{array}{l}\text { Concentration } \\
(\mathrm{mg} / \mathrm{L})\end{array}$ & $\begin{array}{c}\text { Concentration } \\
(\mathrm{mg} / \mathrm{L})\end{array}$ \\
\hline $\begin{array}{c}\text { non-ozonized biochar }+ \text { water } \\
+ \text { HA }\end{array}$ & $2.352 \pm 0.167$ & $3.556 \pm 0.904$ & $3.135 \pm 0.198$ \\
\hline $\begin{array}{l}\text { wet-ozonized biochar }+ \text { water } \\
\qquad+ \text { HA }\end{array}$ & $24.05 \pm 1.68$ & $33.60 \pm 1.38$ & $29.26 \pm 3.74$ \\
\hline $\begin{array}{c}\text { dry-ozonized biochar }+ \text { water } \\
+ \text { HA }\end{array}$ & $19.26 \pm 0.65$ & $25.54 \pm 0.73$ & $26.26 \pm 0.68$ \\
\hline $\begin{array}{c}\text { No Biochar control (water }+ \\
\text { HA only) }\end{array}$ & $1.526 \pm 0.102$ & $2.338 \pm 0.084$ & $2.250 \pm 0.639$ \\
\hline $\begin{array}{c}\text { non-ozonized biochar \& its } \\
\text { filtrate }+ \text { HA }\end{array}$ & $0.095 \pm 0.086$ & $0.04738 \pm 0.08206$ & $1.228 \pm 0.436$ \\
\hline $\begin{array}{c}\text { wet-ozonized biochar \& its } \\
\text { filtrate }+ \text { HA }\end{array}$ & $180.4 \pm 4.2$ & $185.9 \pm 2.1$ & $180.6 \pm 18.0$ \\
\hline $\begin{array}{c}\text { dry-ozonized biochar \& its } \\
\text { filtrate }+ \text { HA }\end{array}$ & $55.06 \pm 3.53$ & $54.11 \pm 5.50$ & $45.70 \pm 12.77$ \\
\hline $\begin{array}{c}\text { non-ozonized biochar filtrate } \\
+ \text { HA }\end{array}$ & $1.208 \pm 0.300$ & $0.1956 \pm 0.3388$ & $2.020 \pm 0.187$ \\
\hline $\begin{array}{c}\text { wet-ozonized biochar filtrate } \\
+\mathrm{HA}\end{array}$ & $170.9 \pm 2.3$ & $172.8 \pm 1.7$ & $152.0 \pm 19.0$ \\
\hline $\begin{array}{c}\text { dry-ozonized biochar filtrate }+ \\
\text { HA }\end{array}$ & $44.28 \pm 0.89$ & $33.00 \pm 7.38$ & $25.60 \pm 14.38$ \\
\hline
\end{tabular}


Table S6: Experimental data on the milli-molar concentration of phosphorus and calcium and the $\mathrm{Ca} / \mathrm{P}$ molar ratio after dissolution for the hydroxyapatite assay. The data is shown for $30 \mathrm{~min}, 2$ days and 14 days of incubation. For the milli-molar concentration the mass of $\mathrm{Ca}^{2+}$ and $\mathrm{PO}_{4}{ }^{3-}$ were divided by their respective molar mass (40.078 and 94.971 respectively). $\mathrm{The} \mathrm{Ca} / \mathrm{PO}_{4}{ }^{3-}$ molar ratio was then determined by dividing the milli-mole of Calcium by that of Phosphate. The initial $\mathrm{Ca} / \mathrm{PO}_{4}{ }^{3-}$ molar ratio within the hydroxyapatite $\mathrm{Ca}_{5}\left(\mathrm{PO}_{4}\right)_{3}(\mathrm{OH})$ is 1.67 as for every 5 moles of calcium there are 3 moles of phosphorus. Phosphorus to phosphate molar ratio is 1:1 therefore the mole of phosphate and the phosphorus are interchangeable. Each measurement is the average of 3 replicates $(n=3)$. Note: HA stands for Hydroxyapatite.

\begin{tabular}{|c|c|c|c|}
\hline & \multicolumn{3}{|c|}{ Phosphorus concentration in $\mathrm{mmol} / \mathrm{L}$ from Hydroxyapatite } \\
\hline & $30 \mathrm{~min}$ & 2 days & 14 days \\
\hline & $\mathrm{mmol} / \mathrm{L}$ & $\mathrm{mmol} / \mathrm{L}$ & $\mathrm{mmol} / \mathrm{L}$ \\
\hline $\begin{array}{c}\text { non-ozonized biochar }+ \text { water } \\
+ \text { HA }\end{array}$ & 0.07592 & 0.1148 & 0.1012 \\
\hline $\begin{array}{c}\text { wet-ozonized biochar }+ \text { water }+ \\
\text { HA }\end{array}$ & 0.7763 & 1.085 & 0.9448 \\
\hline $\begin{array}{c}\text { dry-ozonized biochar }+ \text { water }+ \\
\text { HA }\end{array}$ & 0.6217 & 0.8246 & 0.8478 \\
\hline $\begin{array}{l}\text { No Biochar control (water }+ \\
\text { HA only) }\end{array}$ & 0.04926 & 0.07550 & 0.07262 \\
\hline $\begin{array}{c}\text { non-ozonized biochar \& its } \\
\text { filtrate + HA }\end{array}$ & 0.003059 & 0.001530 & 0.03965 \\
\hline $\begin{array}{l}\text { wet-ozonized biochar \& its } \\
\text { filtrate + HA }\end{array}$ & 5.824 & 6.000 & 5.830 \\
\hline $\begin{array}{l}\text { dry-ozonized biochar \& its } \\
\text { filtrate }+ \text { HA }\end{array}$ & 1.777 & 1.747 & 1.474 \\
\hline $\begin{array}{c}\text { non-ozonized biochar filtrate }+ \\
\text { HA }\end{array}$ & 0.03901 & 0.006315 & 0.06520 \\
\hline $\begin{array}{c}\text { wet-ozonized biochar filtrate }+ \\
\text { HA }\end{array}$ & 5.517 & 5.579 & 4.908 \\
\hline \multirow[t]{4}{*}{$\begin{array}{c}\text { dry-ozonized biochar filtrate }+ \\
\text { HA }\end{array}$} & 1.430 & 1.065 & 0.8265 \\
\hline & \multicolumn{3}{|c|}{ Calcium concentration in $\mathrm{mmol} / \mathrm{L}$ from Hydroxyapatite } \\
\hline & $30 \mathrm{~min}$ & 2 days & 14 days \\
\hline & $\mathrm{mmol} / \mathrm{L}$ & $\mathrm{mmol} / \mathrm{L}$ & $\mathrm{mmol} / \mathrm{L}$ \\
\hline $\begin{array}{c}\text { non-ozonized biochar }+ \text { water } \\
+ \text { HA }\end{array}$ & 0.04795 & 0.0396 & 0.01789 \\
\hline $\begin{array}{c}\text { wet-ozonized biochar }+ \text { water }+ \\
\text { HA }\end{array}$ & 0.3591 & 0.5058 & 0.3155 \\
\hline $\begin{array}{c}\text { dry-ozonized biochar }+ \text { water }+ \\
\text { HA }\end{array}$ & 0.2421 & 0.2123 & 0.2738 \\
\hline $\begin{array}{l}\text { No Biochar control (water }+ \\
\text { HA only) }\end{array}$ & 0.07290 & 0.03000 & 0.07873 \\
\hline
\end{tabular}




\begin{tabular}{|c|c|c|c|}
\hline $\begin{array}{l}\text { non-ozonized biochar \& its } \\
\text { filtrate + HA }\end{array}$ & 0 & 0.01118 & 0.008463 \\
\hline $\begin{array}{l}\text { wet-ozonized biochar \& its } \\
\text { filtrate + HA }\end{array}$ & 1.468 & 1.647 & 0.8358 \\
\hline $\begin{array}{l}\text { dry-ozonized biochar \& its } \\
\text { filtrate + HA }\end{array}$ & 0 & 0.2109 & 0.1567 \\
\hline $\begin{array}{c}\text { non-ozonized biochar filtrate }+ \\
\text { HA }\end{array}$ & 0 & 0 & 0.02627 \\
\hline $\begin{array}{c}\text { wet-ozonized biochar filtrate }+ \\
\text { HA }\end{array}$ & 1.488 & 2.290 & 1.289 \\
\hline \multirow[t]{3}{*}{$\begin{array}{c}\text { dry-ozonized biochar filtrate }+ \\
\text { HA }\end{array}$} & 1.340 & 0.3741 & 0.1696 \\
\hline & \multicolumn{3}{|c|}{ Calcium/Phosphorus mol ratio } \\
\hline & $30 \mathrm{~min}$ & 2 days & 14 days \\
\hline $\begin{array}{c}\text { non-ozonized biochar }+ \text { water } \\
+ \text { HA }\end{array}$ & 0.6316 & 0.3452 & 0.1768 \\
\hline $\begin{array}{c}\text { wet-ozonized biochar }+ \text { water }+ \\
\text { HA }\end{array}$ & 0.4625 & 0.4662 & 0.3340 \\
\hline $\begin{array}{c}\text { dry-ozonized biochar }+ \text { water }+ \\
\text { HA }\end{array}$ & 0.3894 & 0.2575 & 0.3230 \\
\hline $\begin{array}{c}\text { No Biochar control (water }+ \\
\text { HA only) }\end{array}$ & 1.480 & 0.3975 & 1.084 \\
\hline $\begin{array}{c}\text { non-ozonized biochar \& its } \\
\text { filtrate + HA }\end{array}$ & $\mathrm{N} / \mathrm{A}$ & $\mathrm{N} / \mathrm{A}$ & 0.2134 \\
\hline $\begin{array}{c}\text { wet-ozonized biochar \& its } \\
\text { filtrate + HA }\end{array}$ & 0.2521 & 0.2745 & 0.1434 \\
\hline $\begin{array}{c}\text { dry-ozonized biochar \& its } \\
\text { filtrate }+ \text { HA } \\
\end{array}$ & $\mathrm{N} / \mathrm{A}$ & 0.1207 & 0.1062 \\
\hline $\begin{array}{c}\text { non-ozonized biochar filtrate }+ \\
\text { HA }\end{array}$ & $\mathrm{N} / \mathrm{A}$ & $\mathrm{N} / \mathrm{A}$ & 0.4029 \\
\hline $\begin{array}{c}\text { wet-ozonized biochar filtrate }+ \\
\text { HA }\end{array}$ & 0.2696 & 0.4105 & 0.2626 \\
\hline $\begin{array}{c}\text { dry-ozonized biochar filtrate }+ \\
\text { HA }\end{array}$ & 0.9373 & 0.3512 & 0.2052 \\
\hline
\end{tabular}




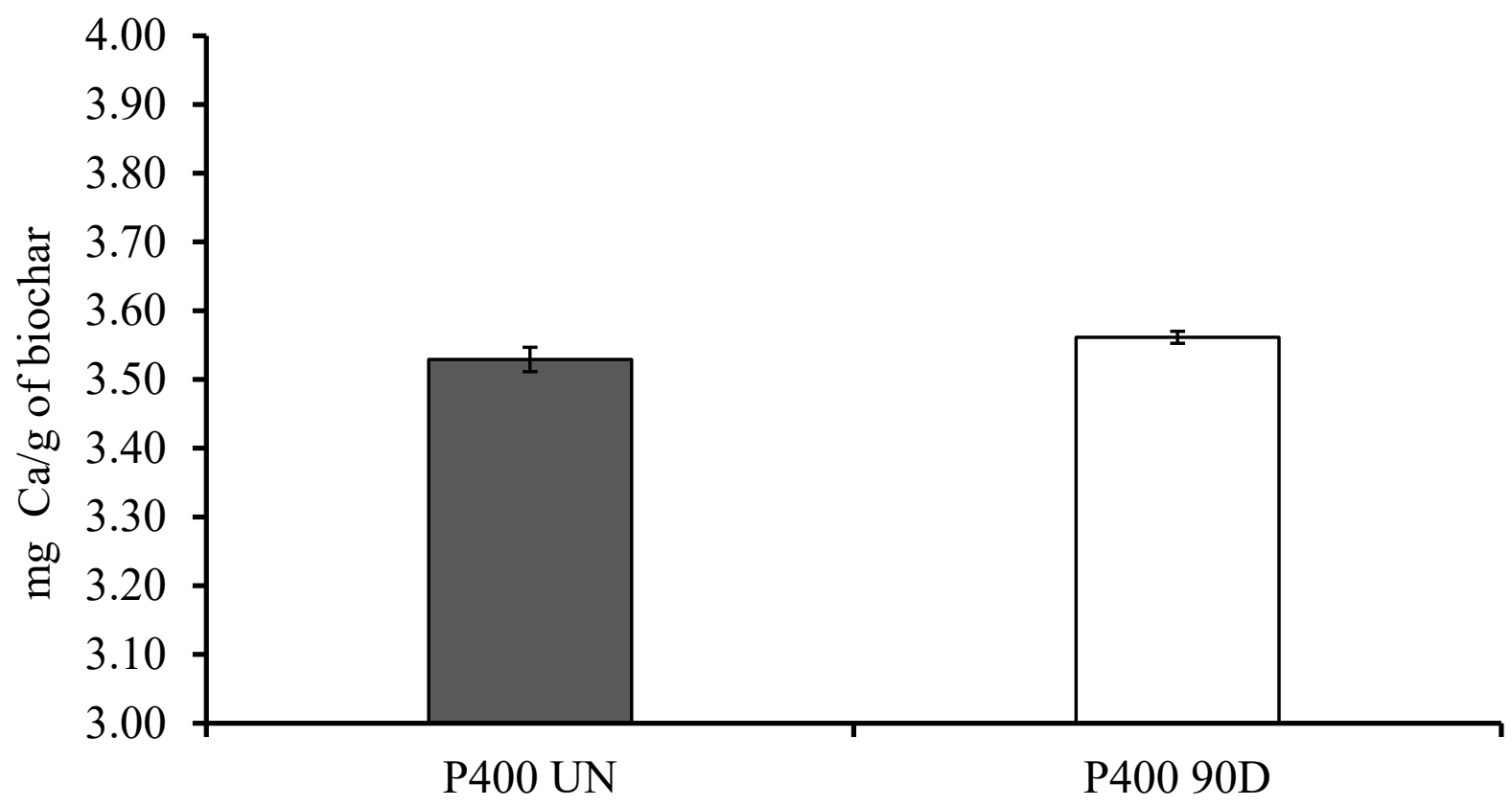

Figure S11: mg of calcium removed per gram of biochar; P400 UN for the non-ozonized pine 400 biochar and P400 90D for the dry-ozonized pine 400 biochar. The values shown are means \pm SD $(n=3)$.

Table S7: Calcium removal from the liquid phase by non-ozonized biochar and dry-ozonized biochar. The removed calcium in percentage, $\mathrm{mg}$ calcium per gram of biochar, mole of calcium per gram of biochar and centimole of calcium per kilogram of biochar are listed as the values of means $\pm \operatorname{SD}(n=3)$.

\begin{tabular}{|c|c|c|}
\hline & $\begin{array}{c}\text { Non-ozone treated } \\
\text { biochar }\end{array}$ & $\begin{array}{c}\text { Dry-ozone treated } \\
\text { biochar }\end{array}$ \\
\hline$\%$ calcium removed & $99.56( \pm 0.24)$ & $98.66( \pm 0.49)$ \\
\hline $\mathrm{mg} \mathrm{Ca} / \mathrm{g}$ of biochar & $3.53( \pm 0.02)$ & $3.56( \pm 0.01)$ \\
\hline $\mathrm{mol} \mathrm{of} \mathrm{Ca}^{2+} \mathrm{removed} / \mathrm{g}$ biochar & $8.81 \mathrm{E}-5( \pm 4.40 \mathrm{E}-7)$ & $8.89 \mathrm{E}-5( \pm 2.16 \mathrm{E}-7)$ \\
\hline $\mathrm{cmol} \mathrm{of} \mathrm{Ca}^{2+} / \mathrm{kg}$ of biochar & $8.81( \pm 0.04)$ & $8.89( \pm 0.02)$ \\
\hline
\end{tabular}

